British \& Irish Botany 1(1): 7-19, 2019

\title{
Dog-roses (Rosa sect. Caninae): towards a consensus taxonomy
}

\author{
Piet Bakker ${ }^{1}$; Bert Maes ${ }^{2}$; Roger Maskew ${ }^{3}$; Clive Stace ${ }^{4}$ \\ ${ }^{1}$ Hilversum, The Netherlands; ${ }^{2}$ Utrecht, The Netherlands; ${ }^{3}$ Stoke Bliss, \\ Worcestershire, UK; ${ }^{4}$ Middlewood Green, Suffolk, UK
}

*Corresponding author: Clive Stace, email: cstace@btinternet.com

This pdf constitutes the Version of Record published on $11^{\text {th }}$ February 2019.

\begin{abstract}
This is an attempt to outline a consensus taxonomy for the dog-roses (Rosa sect. Caninae) of northern, western and central Temperate Europe, including the British Isles, by combining the characteristics of the main British and Continental systems in use today. It involves adopting the slightly narrower species concept of the Continent with the wider recognition of hybrids followed in Britain. The proposed system is based on the traditional view of species of dog-roses; it is considered premature to attempt a 'phylogenetic' system based on the highly fragmentary data that are so far available.
\end{abstract}

Keywords: Rosa canina; species concept; hybridisation; matrocliny; apomixis

\section{The general problem}

Dog-roses (Hondsrozen, Hunds-Rosen, Rosa sect. Caninae) are one part of a small number of genera in which essentially the same group of taxa is classified (and therefore identified) differently in different countries or regions. This is, of course, scientifically unjustifiable. In attempting to explore the possibility of a consensus taxonomy for dog-roses, four botanists (rose-experts Piet Bakker and Bert Maes from the Netherlands, and Clive Stace and rose-expert Roger Maskew from England) paid reciprocal visits to their two countries in August 2014. The main objectives were to discover (a) whether the two rose floras were substantially the same or exhibited significant differences, and (b) whether there were any differences between the experts in their determinations.

We unanimously concluded that differences in the floras are relatively minor. In Britain there is no $R$. elliptica or $R$. inodora, and the Netherlands lack $R$. stylosa and $R$. mollis. In the great majority of cases the Dutch and English determinations of wild rose bushes were the same, although sometimes under different names. The only recurrent difference encountered was that the Dutch concept of most species is broader, including specimens that in England would be considered as hybrids. The unequal (caninatype) meiosis of dog-roses of course contributes to this difference, because hybrids usually more closely (often much more closely) resemble their female parent (matroclinous inheritance). Roses that would be identified as hybrids by British botanists were no less frequently encountered in the Netherlands than in England. 
We concluded from the above that differences between the classifications adopted are based on a combination of historical, theoretical and subjective decisions rather than on different biological situations in the two regions. Therefore, attaining a mutually acceptable consensus should be feasible.

We are confining this discussion to the floras of central, northern and western Temperate Europe (i.e. excluding the Mediterranean region, the Alpes and Europe east of the eastern borders of Finland-Baltic states-Poland-Slovakia-Hungary; and south of the southern borders of Hungary-Austria-Switzerland-temperate France). According to Flora Europaea (Klášterský 1968), Atlas Florae Europaeae (Kurtto 2004) and Hegi's Flora (Henker, 2000) ten extra species just cross the eastern or southern limits of our designated area:

Subsect. Caninae - R. abietina, R. chavinii, R. montana, R. pouzinii, R. rhaetica, R. uriensis.

Subsect. Rubigineae - R. caryophyllacea, R. pulverulenta ( $R$. sicula), R. serafinii, R. zalana.

We have not considered these species because of our relatively poor knowledge of the dog-roses of these eastern and southern geographical areas. We are also considering only those taxa which are native to our area.

For the present we are not considering the use of subspecies. This is a complicating factor which could be discussed at a later date. Subspecies have been used, for example, in $R$. villosa (for $R$. mollis), $R$. caesia (for $R$. dumalis/R. vosagiaca) and $R$. dumalis/R. vosagiaca (for $R$. subcanina and $R$. subcollina), but they have also all been treated at species level in the past and we shall consider them as such.

\section{Taxonomic background}

Section Caninae can be defined in morphological terms, and also on the basis of its possession of canina-type meiosis, the species varying from tetraploid to hexaploid (mainly pentaploid). The number of species recognised has varied considerably over the years, and today still does so according to taxonomic opinion. For example, the standard British work (Graham \& Primavesi, 1993) recognises 10 native species (Table 1). Applying the species concepts of the Dutch standard work (Bakker, Maes \& Kruijer, 2011) and of the current German list (Buttler et al., 2016) to the British list the total would become 17, and using that of Flora Europaea (Klášterský, 1968) it would be 20 (Table 1).

The accounts in Atlas Florae Europaeae (Kurtto et al., 2004) and Hegi's Flora (Henker, 2000) do not differ significantly from that in Buttler et al. (2016). According to Flora Gallica (Mercier, 2014) there would be only 5 British species ( $R$. canina, $R$. tomentosa, $R$. villosa, $R$. rubiginosa, $R$. agrestis) and according to van der Meijden (Heukels' Flora van Nederland, 2005) only three ( $R$. canina, $R$. villosa, $R$. rubiginosa, which correspond to the three subsections represented in the Netherlands). In earlier times, in parts of the $19^{\text {th }}$ century and the start of the $20^{\text {th }}$ century, many more British species, even over 100, were sometimes recognised, and Déséglise (1876) published 405 Rosa species for Europe, Asia and Africa, "specially the roses from France and England".

Some rhodologists have expressed the view that almost no two rose plants are identical, so that one could recognise as many species as one wished according to 
how narrowly one drew the limits. The number of taxa described, including varieties, is several thousand (4266 according to Gandoger, 1892-3).

Table 1. Species of West European Rosa sect. Caninae recognised by Graham et al. (1993), Bakker et al. (2011), Buttler et al. (2014) and Klášterský (1968)

\begin{tabular}{|c|c|c|c|}
\hline GRAHAM et al. & BAKKER et al. & BUTTLER et al. & KLÁŠTERSKÝ \\
\hline & & glauca & glauca \\
\hline stylosa & & stylosa & stylosa \\
\hline (hybrid) & & & andegavensis \\
\hline \multirow[t]{3}{*}{ canina } & canina & canina & canina \\
\hline & corymbifera & corymbifera & corymbifera \\
\hline & & & squarrosa \\
\hline (hybrid) & & & deseglisei \\
\hline (hybrid) & subcanina & subcanina & subcanina \\
\hline (hybrid) & subcollina & subcollina & subcollina \\
\hline caesia subsp. caesia & caesia & caesia & caesia \\
\hline caesia subsp. glauca & dumalis & dumalis & vosagiaca \\
\hline obtusifolia & balsamica & balsamica & obtusifolia \\
\hline tomentosa & tomentosa & tomentosa & tomentosa \\
\hline (hybrid) & pseudoscabriuscula & pseudoscabriuscula & scabriuscula \\
\hline \multirow[t]{2}{*}{ sherardii } & sherardii & sherardii & sherardii \\
\hline & villosa & villosa & villosa \\
\hline mollis & & mollis & mollis \\
\hline (hybrid) & & & nitidula \\
\hline rubiginosa & rubiginosa & rubiginosa & rubiginosa \\
\hline (hybrid) & henkeri-schulzei & gremlii & \\
\hline micrantha & micrantha & micrantha & micrantha \\
\hline \multirow[t]{4}{*}{ agrestis } & agrestis & agrestis & agrestis \\
\hline & elliptica & elliptica & elliptica \\
\hline & inodora & inodora & \\
\hline & & marginata & jundzillii \\
\hline
\end{tabular}

We have rejected, at least for the present, the novel classification adopted in Flora Gallica (Mercier, 2014), which recognises two sorts of species: mayrons (diploid or tetraploid species with a normal meiosis); and kleptons (tetraploids to hexaploids with canina-type meiosis). We are concerned here with only the 'kleptons' (sect. Caninae). The 20 (17 British +3 extra Dutch, i.e. the non-British $R$. villosa*, $R$. elliptica, $R$. inodora) species of 'kleptons' recognised in total by the Dutch/British rhodologists are reduced in Flora Gallica to 5 ( $R$. elliptica \& $R$. inodora included in $R$. 
agrestis, $R$. micrantha \& $R$. gremliil henkeri-schulzii included in $R$. rubiginosa; $R$. mollis included in $R$. villosa; $R$. sherardii \& $R$. pseudoscabriuscula included in $R$. tomentosa agg.; $R$. stylosa, $R$. obtusifolial balsamica, $R$. caesia, $R$. dumalis/vosagiaca, $R$. corymbifera, $R$. subcanina \& $R$. subcollina (and also the Central European $R$. abietina) included in $R$. canina agg.). Such a system would not satisfy the needs of field botanists who can, and regularly do, recognise most of the above relegated taxa and need binomials for them. It is fair to note that Mercier admitted that his concept of the kleptons is broad, and that more detailed study might reveal further distinctive taxa that deserve specific recognition. He actually listed eight 'groupes' within $R$. canina agg. and two or three 'phénotypes' in several others.

[*In $2015 R$. villosa became recognised as a rare naturalised alien in Britain.]

It is clear that all the roses in this polyploid group are hybrid in origin, a varying number of which have been recognised as species. If we look at extremes amongst these hybridogenous taxa we see, for example, on the one hand taxa like $R$. canina, accepted by all taxonomists as a common and widespread species throughout Europe and beyond, and on the other hand taxa like $R$. agrestis $R$. micrantha $=R$. $\mathrm{x}$ bishopii, a rare partially fertile hybrid which has never accorded specific status and which as far as we know has been found only in a few places in southern Britain. Since all the taxa are hybridogenous it becomes a question of which of them should be recognised as species (without an ' $x$ '), and which as hybrids, with a formula and often (ideally) a binomial with an ' $x$ '.

Six points seem to us to be relevant in any discussion of Caninae taxonomy:

1. Studies in the British Isles and on the Continent show that any two species of dog-rose that coexist can hybridise (and can often hybridise with species in other sections). Hence the more species that are accepted, the more interspecific hybrids will have to be recognised.

2. Although we can see the reasoning behind it, we do not consider that a system which accepts both species and hybrids among the intermediates between any two species could justify the considerable complications in naming that would arise; simplification rather than complication is our aim. One example is the use of both $R$. gremlii ( $R$. henkeri-schulzei) and $R$. micrantha $\mathrm{R}$. rubiginosa $=R . \mathrm{x}$ bigeneris to represent the intermediates between $R$. micrantha and $R$. rubiginosa; Another is the intermediates between $R$. tomentosa and $R$. sherardii, known as the hybrid $R . \mathrm{x}$ suberectiformis in Britain, but as the species $R$. pseudoscabriuscula on the Continent.

3. It does not seem that fertility/sterility can be used as a reliable criterion of hybridity. Some of the interspecific dog-rose hybrids are highly fertile, many are partially fertile, and a few are totally sterile. Overall they are more fertile than hybrids between dog-roses and species of other sections. The relatively recent discovery of true apomixis in dog-roses (Werlemark et al. 1999, Werlemark 2000, Werlemark \& Nybom 2001) indicates that hybrids which otherwise would be sexually sterile might appear fertile. For example, the unexpected fertility and lack of segregation shown by a clone of $R$. sherardii $\mathrm{x} R$. mollis in Scotland (which was described as a new species, $R$. perthensis, by Rouy (1900)) might well be explained by apomixis, which equally could 
explain the uniform appearance of the offspring of other hybrids. It is not known how common apomixis is, but its existence must greatly reduce the value of fertility as a criterion. Note that this true apomixis is different from the effects of canina-type meiosis, which has been described as 'hemisexuality' or 'partial apomixis' in the past, and as 'tychopoïès' in Flora Gallica.

4. Ritz \& Wissemann (2003) concluded that pubescence of leaves, presence of glands on leaf surface and pedicels, and epicutilar wax sculptures are inherited maternally, and that diameter of hip disc orifice and sepal persistence and disposition are inherited paternally. The universality and absolute nature of this claim need to be investigated more widely, and has to be firmly established before the data are used to revise classifications. They investigated only five species and their interspecific hybrids, and in fact not all the results of Ritz \& Wissemann's important experiments followed this pattern of inheritance (e.g. $R$. rubiginosa $\mathrm{x}$ micrantha sepal persistence). Is it really true, for example, that the hybrid $R$. canina (female) $x R$. tomentosa is completely hairless? If it is so, then it will be impossible to distinguish, inter alia, $R$. caesia $\times$. canina from $R$. caesia $\times$. corymbifera.

5. It has long been recognised (and recently reiterated by Bakker et al. and Mercier) that certain diagnostic characters of dog-roses are correlated, allowing two informal groups to be recognised: (a) Bushes dense and arching, disc flat or weakly concave and with an orifice $>1.2 \mathrm{~mm}$ wide, sepals spreading to erect at fruiting and persistent, stigmas woolly and forming a hemispherical dome covering most of the disc, petals deeper pink (D phenotype); (b) Bushes open and erect, disc flat, convex or conical and with an orifice $<0.8 \mathrm{~mm}$ wide, sepals reflexed at fruiting and soon deciduous, stigmas glabrous or sparsely hairy and forming a loose mass not covering the disc, petals white or pale pink (L phenotype). Forming a third informal group are the intermediates between $D$ and $L$ phenotypes,known as $\mathbf{D} / \mathbf{L}$ phenotypes. Following from (4) above, the disc and sepal characters of hybrids are inherited from the male parent. It should be noted that several of the realignments of Mercier (e.g. sherardii \& tomentosa, caesia \& canina and micrantha \& rubiginosa) involved amalgamations of D- and L-species.

6. In recent years there have been some attempts to construct a so-called phylogenetic classification for dog-roses (Mercier, 2014; Haveman, 2016). In such a classification it is suggested that only the female-derived characters, and not the paternally derived characters (hip orifice and sepal characters), should be used in classification. Mercier's classification is an attempt towards such a phylogenetic classification, but his proposed kleptons are not compatible with present systems of classification, since several currently accepted species are split across more than one klepton (e.g. $R$. sherardii pro parte and $R$. balsamica pro parte each appear under two different kleptons) and there are some novel amalgamations (e.g. R. caesia (D) and $R$. stylosa (L) united in one klepton). The current wide incompatibility of the two systems and our hugely incomplete knowledge of the evolution of sect. Caninae indicates that we are not yet near the time when the current widely accepted 'typological' system, based upon observed phenotypes, can be 
abandoned. Unfortunately the papers by Koopman et al. (2008), De Riek et al. (2013) and Fougère-Danezan (2015) have not yet sufficiently clarified dog-rose phylogeny.

It seems to be very widely accepted that dog-roses which are 'stabilised', relatively ancient, well-distributed (sometimes beyond the area of overlap of the two parents) and common in their area, and usually whose parentage is not obvious, should be regarded as species (exemplified by $R$. canina above), but that dog-roses which are relatively recent in origin, sporadic and usually confined to areas of overlap of the two parents should be treated as interspecific hybrids (exemplified by $R . x$ bishopii above). In the latter case the parentage is usually evident. Although this view is apparently uncontentious (reiterated by, for example, Buttler (2016)), all intermediates exist and there is no agreement as to where the line should be drawn. The existence of obvious parents presumably points to a relatively recent origin for a hybrid, and their absence is likely to suggest a more distant origin, and this might be useful in defining the line. It is a common problem that one parent is obvious but the second is more doubtful, due to no suitable candidate being present in the vicinity. This applies, i.a., to Carex, Epilobium and Salix as well as to Rosa; sometimes the identity of a hybrid is uncertain, and we have to accept that. There are also two other problems: a hybrid might appear to be 'stabilised' and common in one area, but sporadic and rare in another; and in different areas a different form of a particular hybrid combination might become 'stabilised'. Hence the more hybrids that are recognised as species, the greater will be the range of taxonomic opinion between different regions, and the more interspecific hybrids will need to be recognised.

\section{The points of difference}

The different opinions about species limits, i.e. the number of species recognised, in European dog-roses can nearly all be assigned to one of two causes: splitting or lumping of some taxa; and recognition of taxa either as species or as hybrids. The contrasting opinions that we are here discussing can be summarised as the 'British' (Graham \& Primavesi) and 'Continental' (Dutch/German/Hegi/Flora Europaea/Atlas Florae Europaeae) schools (BS and CS respectively)

1. Splitting/lumping.

a. Rosa caesia (BS) is divided into R. caesia and R. dumalis/vosagiaca (CS); these were recognised as subsp. caesia and subsp. vosagiaca (or glauca) by Graham \& Primavesi (1993).

b. Rosa canina (BS) is divided into $R$. canina and $R$. corymbifera, and sometimes also into $R$. squarrosa (CS); these were recognised as three informal groups (Lutetianae, Pubescentes, Dumales) of $R$. canina by Graham \& Primavesi (1993).

c. Rosa mollis and $R$. villosa are treated as subspecies of $R$. villosa in some CS treatments.

2. Species/hybrids.

Eight taxa that are or would be (if they occurred in Britain) treated as hybrids in BS are given specific status in various CS treatments. Their parentage does not seem to be in dispute, except for $R$. subcollina.

$R$. pseudoscabriuscula ( $=R$. sherardiix $R$. tomentosa) 
R. gremlii ( $R$. henkeri-schulzel) ( $=R$. micrantha $\times$ R. rubiginosa)

$R$. inodora $(=R$. agrestis $\times R$. elliptica)

$R$. nitidula ( $=R$. canina $\times$. rubiginosa)

$R$. subcollina $(=R$. caesia $\times$ R. canina or $R$. corymbifera)

$R$. subcanina ( $=R$. canina $\times$ R. dumalis/vosagiaca)

$R$. andegavensis ( $=R$. canina $\times$ R. stylosa)

$R$. scabriuscula ( $=R$. canina $\times R$. tomentosa)

The first six of these eight are hybrids between species with the $D$ and $L$ phenotypes ( $D / L$ phenotype), the last two have the $L$ phenotype. The data overall suggest that all taxa with the L/D phenotype are relatively recent hybrids, although the genetic analyses of Ritz \& Wissemann (2003) and Herklotz \& Ritz (in litt., 2016) did not show this.

3. Apart from the above taxonomic considerations, a few nomenclatural issues need to be settled. The principal ones are listed here, but this document does not aim to address the matter in any detail.

- Application of $R$. scabriuscula. Graham \& Primavesi (1990) lectotypified this taxon on a specimen in LIV, which they determined as $R$. canina $R$. tomentosa.

- $R$. pseudoscabriuscula/suberectiformis. This taxon is considered to represent $R$. sherardiix $R$. tomentosa; $R$. suberectiformis Wolley-Dod is the earlier name.

- R. henkeri-schulzeil gremlii/bigeneris/columnifera auct. Rosa gremlii (Christ) Christ ex Gremli is the earliest of these four names for $R$. micrantha $\times$ R. rubiginosa.

- Application of $R$. dumalis Bechst. This has usually been used for $R$. vosagiaca, but the admittedly inadequate description by Bechstein led Graham \& Primavesi to conclude that it is the hybrid $R$. canina s.l. x $R$. vosagiaca. The description by Bechstein of red glandular biserrate leaflets and densely red glandular serrate stipule margins indicates that the precise parentage was $R$. squarrosa $R$. vosagiaca. Because Bechstein's type no longer exists, in 1995 Loos (1996) designated a neotype, which was examined by Tony Primavesi and Roger Maskew in 2002; this was found to agree closely with Bechstein's description and with living plants considered by Primavesi and Maskew to be the hybrid $R$. squarrosa $R$. vosagiaca. Since $R$. dumalis is not applicable to the species in question, $R$. vosagiaca (N.H.F. Desp.) Déségl. becomes the earliest available name.

- Application of $R$. dumetorum Thuill. The type in $\mathrm{G}$ was examined by Graham \& Primavesi (1990) and identified as R. canina x R. obtusifolia (tomentella).

- $R$. obtusifolia versus $R$. balsamica. Recent investigations by Roger Maskew have indicated that $R$. obtusifolia Desv. is a synonym of $R$. corymbifera, and that $R$. balsamica Besser represents hybrid entities. The correct name for this taxon appears to be $R$. tomentella Léman.

- $R$. squarrosa versus $R$. scabrata. $R$. scabrata Crép. is predated by $R$. scabrata J. Henning, but is in any case later than $R$. squarrosa (Rau) Boreau. 
- $\quad R$. ferruginea versus $R$. glauca. Recently $R$. ferruginea Vill. has been declared a nomen rejiciendum, so the correct name for this taxon is $R$. glauca Pourr. $R$. rubrifolia Vill. is illegitimate.

- $R$. jundzillii Besser versus $R$. marginata Wallr. $R$. marginata has priority. We have been careful to apply the rules of the International Code, notably the principle of priority, as precisely as we are able, even though that has inevitably involved the replacement or reapplication of some much-used names.

\section{Consensus involves compromise}

We reiterate here the belief that having different classifications in different regions is not scientifically justified and is unsustainable, because international comparisons are not possible and a Europe-wide synthesis could not be achieved. We propose a compromise which follows both

- the more species-splitting system favoured on the Continent, and

- the recognition as nothotaxa of the many widespread hybrids between this core of species (as practised for 40 years in Britain) rather than as species (as practised by some Continental specialists).

In systems that recognise more than this core of species, many hybrids that certainly exist, e.g. between $R$. subcanina and all other species of dog-rose, have been largely ignored.

Our proposal therefore recognises the seventeen species listed in Table 2, i.e. stabilised, probably relatively ancient, well-distributed taxa, mostly with an unknown parentage; their L- or D-type morphology is indicated.

Table 2. The seventeen West European species of Rosa sect. Caninae recognised in this study

D = D-type; L = L-type

\begin{tabular}{|c|c|}
\hline Subsect. RUBRIFOLIAE & Subsect. VESTITAE \\
\hline R. glauca Pourr. (D) & R. tomentosa $\mathrm{Sm} .(\mathrm{L})$ \\
\hline Subsect. CANINAE & R. sherardii Davies (D) \\
\hline R. canina L. (L) & R. mollis Sm. (D) \\
\hline R. corymbifera Borkh. (L) & R. villosa L. (D) \\
\hline R. squarrosa (A. Rau) Boreau (L) & Subsect. RUBIGINEAE \\
\hline R. tomentella Léman (L) & R. rubiginosa L. (D) \\
\hline R. caesia Sm. (D) & R. elliptica Tausch (D) \\
\hline$R$. vosagiaca (N.H.F. Desp.) Déségl. (D) & $R$. agrestis Savi (L) \\
\hline \multirow[t]{3}{*}{ R. stylosa Desv. (L) } & R. micrantha Borrer ex Sm. (L) \\
\hline & Subsect. TRACHYPHYLLAE \\
\hline & R. marginata Wallr. (L) \\
\hline
\end{tabular}

We propose that the eight hybrid taxa listed under paragraph (2) on pages 6-7 should be recognised and designated as hybrids, e.g. $R$. canina $R$. rubiginosa $=R$. $\mathrm{x}$ nitidula, not as species, as is normal for hybrids. They are listed in Table 3, together with the many other interspecific hybrids involving dog-roses that have 
been identified in the region, mainly in the British Isles and Germany. Provision of this lengthy, yet certainly far from complete, list illustrates the size of the practical and theoretical problem presented by hybridisation in dog-roses. The known distribution of these hybrids is given for the British Isles (BI), the Netherlands ( $\mathrm{Ho})$ and Germany (Ge) only. Descriptions of all 73 hybrids listed in Table 3 as recorded in the British Isles are given by Maskew (2015).

Table 3. List of interspecific hybrids involving Rosa sect. Caninae recorded from the British Isles (BI), The Netherlands (Ho) and Germany (Ge)

\section{(1) Hybrids within section Caninae}

\begin{tabular}{|c|c|c|c|}
\hline$R$. agrestis $\times R$. canina $=R . \times$ belnensis Ozanon & BI & Ge & \\
\hline R. agrestis $\times$ R. corymbifera & BI & $\mathrm{Ge}$ & \\
\hline$R$. agrestis $\times R$. elliptica $=R . \times$ inodora $\mathrm{Fr}$. & & $\mathrm{Ge}$ & Ho \\
\hline R. agrestis $\times R$. micrantha $=R . \times$ bishopii Wolley-Dod & BI & & \\
\hline$R$. agrestis $\times R$. sherardii & $\mathrm{BI}$ & & \\
\hline$R$. agrestis $\times$ R. stylosa & BI & & \\
\hline$R$. agrestis $\times R$. tomentosa & BI & & \\
\hline $\begin{array}{l}\text { R. caesia } \times \text { R. canina }=R . \times \text { subcollina (Christ) Vuk. pro } \\
\text { parte }\end{array}$ & BI & $\mathrm{Ge}$ & $\mathrm{Ho}$ \\
\hline $\begin{array}{l}\text { R. caesia } \times \text { R. corymbifera }=R . \times \text { subcollina (Christ) Vuk. } \\
\quad \text { pro parte }\end{array}$ & BI & Ge & Ho \\
\hline R. caesia $\times$ R. mollis $=R . \times$ glaucoides Wolley-Dod & BI & & \\
\hline R. caesia $\times$ R. rubiginosa & BI & & \\
\hline R. caesia $\times$ R. sherardii & BI & & \\
\hline R. caesia $\times$ R. vosagiaca & BI & & \\
\hline R. canina $\times$ R. corymbifera & BI & & Ho \\
\hline R. canina $\times$ R. glauca & & $\mathrm{Ge}$ & \\
\hline R. canina $\times$ R. marginata & & $\mathrm{Ge}$ & \\
\hline R. canina $\times R$. micrantha $=R . \times$ toddiae Wolley-Dod & BI & & \\
\hline$R$. canina $\times R$. mollis $=R . \times$ molletorum Hesl.-Harr. & BI & & \\
\hline$R$. canina $\times$ R. rubiginosa $=R . \times$ nitidula Besser & $\mathrm{BI}$ & $\mathrm{Ge}$ & $\mathrm{Ho}$ \\
\hline$R$. canina $\times R$. sherardii $=R . \times$ rothschildii Druce & BI & & \\
\hline R. canina $\times$ R. squarrosa & & & $\mathrm{Ho}$ \\
\hline$R$. canina $\times R$. stylosa $=R . \times$ andegavensis Bastard & BI & & Ho \\
\hline$R$. canina $\times R$. tomentella $=R . \times$ dumetorum Thuill. & BI & & $\mathrm{Ho}$ \\
\hline$R$. canina $\times$ R. tomentosa $=R . \times$ scabriuscula Sm. & BI & Ge & \\
\hline$R$. canina $\times$ R. vosagiaca $=R . \times$ subcanina (Christ) Vuk. & $\mathrm{BI}$ & $\mathrm{Ge}$ & $\mathrm{Ho}$ \\
\hline R. corymbifera $\times$ R. marginata & & $\mathrm{Ge}$ & \\
\hline R. corymbifera $\times$ R. micrantha & & $\mathrm{Ge}$ & \\
\hline$R$. corymbifera $\times$ R. mollis & BI & & \\
\hline
\end{tabular}




\begin{tabular}{|c|c|c|c|}
\hline R. corymbifera $\mathrm{x}$ R. sherardii & BI & & \\
\hline R. corymbifera $\mathrm{R}$. squarrosa & BI & & \\
\hline$R$. corymbifera $\times R$. stylosa $=R . \times$ rufescens Wolley-Dod & BI & & \\
\hline R. corymbifera $\times$ R. tomentella & BI & & \\
\hline$R$. corymbifera $\times R$. tomentosa $=R . \times$ aberrans Wolley-Dod & $\mathrm{BI}$ & $\mathrm{Ge}$ & \\
\hline R. corymbifera $\times$ R. vosagiaca & BI & & \\
\hline R. elliptica $\times$ R. vosagiaca & & $\mathrm{Ge}$ & \\
\hline R. glauca $\times$ R. vosagiaca & & $\mathrm{Ge}$ & \\
\hline R. marginata $\times$ R. vosagiaca & & $\mathrm{Ge}$ & \\
\hline $\begin{array}{l}\text { R. micranthax } R . \text { rubiginosa }=R . \times \text { gremlii (Christ) Christ } \\
\text { ex Gremli ( } R . \times \text { henkeri-schulzei Wissemann, } R . \mathrm{x} \\
\text { bigeneris Duffort ex Rouy, } R . \text { columnifera } \\
\text { (Schwertschl.) Henker \& G. Schulze non Fr.) }\end{array}$ & BI & $\mathrm{Ge}$ & Ho \\
\hline R. micrantha $\times$ R. sherardii & BI & & \\
\hline R. micrantha $\mathrm{x}$ R. tomentella & BI & & \\
\hline R. micrantha $\mathrm{x}$. tomentosa & BI & & \\
\hline $\begin{array}{l}\text { R. micrantha } \mathrm{R} \text {. vosagiaca }=R . \mathrm{x} \text { longicolla Ravaud ex } \\
\text { Rouy }\end{array}$ & $\mathrm{BI}$ & Ge & \\
\hline R. mollis $\times$ R. rubiginosa $=R . \times$ molliformis Wolley-Dod & BI & & \\
\hline R. mollis $\times$ R. sherardii $=R . \times$ perthensis Rouy & BI & & \\
\hline R. mollis $\times$ R. tomentosa & BI & & \\
\hline R. mollis $\times$ R. vosagiaca & $\mathrm{BI}$ & & \\
\hline R. rubiginosa $\times$ R. sherardii $=R . \times$ suberecta (Woods) Ley & $\mathrm{BI}$ & & \\
\hline R. rubiginosa $\times$ R. stylosa $=R$. x bengyana Rouy & BI & & \\
\hline$R$. rubiginosa $\times R$. tomentella $=R . \times$ timbalii Crép. & BI & & \\
\hline R. rubiginosa $\times$ R. tomentosa $=R . \times$ avrayensis Rouy & $\mathrm{BI}$ & $\mathrm{Ge}$ & \\
\hline R. rubiginosa $\times$ R. vosagiaca & BI & $\mathrm{Ge}$ & \\
\hline R. sherardii $\times$ R. stylosa & BI & & \\
\hline R. sherardii $\times$ R. tomentella & BI & & \\
\hline $\begin{array}{l}\text { R. sherardii } \times \text { R. tomentosa }=R . \times \text { suberectiformis Wolley- } \\
\text { Dod }(R . \times \text { pseudoscabriuscula (R. Keller) Henker \& G. } \\
\text { Schulze) }\end{array}$ & $\mathrm{BI}$ & Ge & Ho \\
\hline R. sherardii $\times$ R. vosagiaca & $\mathrm{BI}$ & Ge & \\
\hline R. squarrosa $\mathrm{x}$ R. stylosa & BI & & \\
\hline R. squarrosa $\mathrm{R}$ R. tomentosa & $\mathrm{BI}$ & & \\
\hline R. squarrosa $\times$ R. vosagiaca $=R . \times$ dumalis Bechst. & BI & & \\
\hline R. stylosa $\times$ R. tomentella & BI & & \\
\hline R. stylosa $\mathrm{x}$ R. vosagiaca & BI & & \\
\hline R. tomentella $\times$ R. tomentosa & BI & & \\
\hline
\end{tabular}




\begin{tabular}{|l|l|l|l|}
\hline$R$. tomentella $\times$ R. vosagiaca & $\mathrm{BI}$ & & \\
\hline$R$. tomentosa $\times$ R. vosagiaca & $\mathrm{BI}$ & $\mathrm{Ge}$ & \\
\hline
\end{tabular}

(2) Hybrids between sections Caninae and Synstylae

\begin{tabular}{|c|c|c|}
\hline R. arvensis $\times$ R. caesia & $\mathrm{BI}$ & \\
\hline$R$. arvensis $\times R$. canina $=R . \times$ irregularis Déségl. \& Guillon & $\mathrm{BI}$ & $\mathrm{Ge}$ \\
\hline$R$. arvensis $\times R$. corymbifera $=R . \times$ deseglisei Boreau & $\mathrm{BI}$ & \\
\hline$R$. arvensis $\times R$. micrantha $=R . \times$ vituperabilis Duffort ex Rouy & $\mathrm{BI}$ & \\
\hline$R$. arvensis $\times R$. tomentella $=R . \times$ rouyana Duffort ex Rouy & $\mathrm{BI}$ & \\
\hline$R$. arvensis $\times R$. rubiginosa $=R . \times$ gallicoides (Baker) Déségl. & $\mathrm{BI}$ & \\
\hline$R$. arvensis $\times R$. squarrosa & $\mathrm{BI}$ & \\
\hline$R$. arvensis $\times$ R. sherardii & $\mathrm{BI}$ & \\
\hline $\begin{array}{l}\text { R. arvensis } \times R . \text { stylosa }=R . \times \text { pseudorusticana Crép. ex } \\
\text { Preston }\end{array}$ & $\mathrm{BI}$ & \\
\hline R. arvensis $\times$ R. tomentosa & $\mathrm{BI}$ & \\
\hline$R$. arvensis $\times R$. vosagiaca & $\mathrm{BI}$ & \\
\hline
\end{tabular}

(3) Hybrids between sections Caninae and Pimpinellifoliae

\begin{tabular}{|c|c|c|}
\hline $\begin{array}{l}R . \text { spinosissima } \times \text { R. caesia }=R . \times \text { margerisonii (Wolley-Dod) } \\
\text { Wolley-Dod }\end{array}$ & $\mathrm{BI}$ & \\
\hline$R$. spinosissima $\times R$. canina $=R . \times$ grovesii (Baker) Maskew & $\mathrm{BI}$ & $\mathrm{Ge}$ \\
\hline$R$. spinosissima $\times R$. corymbifera $=R . \times$ hibernica Templeton & $\mathrm{BI}$ & \\
\hline R. spinosissima $\times$ R. elliptica & & $\mathrm{Ge}$ \\
\hline R. spinosissima $\times$ R. mollis $=\mathrm{R} . \times$ sabinii Woods & $\mathrm{BI}$ & \\
\hline R. spinosissima $\times R$. rubiginosa $=R . \times$ biturigensis Boreau & BI & $\mathrm{Ge}$ \\
\hline$R$. spinosissima $\times R$. sherardii $=R . \times$ involuta $\mathrm{Sm}$. & $\mathrm{BI}$ & \\
\hline R. spinosissima $\times$ R. tomentosa $=R . \times$ andrzejowskii Boreau & $\mathrm{BI}$ & $\mathrm{Ge}$ \\
\hline R. spinosissima $\times$ R. vosagiaca & $\mathrm{BI}$ & $\mathrm{Ge}$ \\
\hline
\end{tabular}

As stated above, acceptance of this scheme and its application to the regional Rosafloras of northern, western and central Temperate Europe represents a compromise, one that means that we will all need to rethink some of our previous decisions, but we strongly believe that it represents a system that gives names to recognisable entities, and that its adoption would provide a classification which would enable constructive comparisons between different regions of Europe and which would prove taxonomically durable. The evolutionary history of dog-roses is not yet understood fully and a system that closely reflects it is still a long way off; in the interim a truly international system based on morphological entities is required, and we recommend the one proposed here. 


\section{Acknowledgements}

We are most grateful to the Botanical Research Fund for a grant enabling our reciprocal visits between England and The Netherlands in 2014.

\section{References}

Very numerous publications have been consulted in this project, from 1753 to 2018, but only those referred to in the text are listed below.

Bakker, P.A., Maes, N.C.M. \& Kruijer, J.D. 2011. De wilde rozen (Rosa L.) van Nederland. Gorteria, 35: 1-173.

Buttler, K.P., Thieme, M. et al. 2016. Florenliste von Deutschland - Gefässpflanzen, Version 8 (August 2016). http://www.kp-buttler.de/florenliste.

De Riek, J., De Cock, K., Smulders, M.J.M. \& Nybom, H. 2013. AFLP-based population structure analysis as a means to validate the complex taxonomy of dogroses (Rosa section Caninae). Molecular Phylogenetics and Evolution, 67: 547-559.

Déséglise, A. 1876. Catalogue raisonné ou énumeration méthodique des espèces du genre Rosier pour Europa, I'Asie et de l'Afrique spécialement les rosiers de la France et de l'Angleterre. Geneva: Mentz.

Fougère-Danezan, M., Joly, S., Bruneau, A., Xin-Fen Gao \& Li-Bing Zhang 2015. Phylogeny and biogeography of wild roses with specific attention to polyploids. Annals of Botany, 115: 275 - 291.

Gandoger, M. 1892-3. Monographia Rosarum Europae et Orientalis et terrarium adjacentium, 1-4. Paris: F. Savy, J.-B. Ballière.

Graham, G.G. \& Primavesi, A.L. 1990. Notes on some Rosa taxa recorded as occurring in the British Isles. Watsonia, 18: 119-124.

Graham, G.G. \& Primavesi, A.L. 1993. Roses of Great Britain and Ireland. London: Botanical Society of the British Isles.

Haveman, R. 2016. Gestolen kenmerken: wat zijn soorten in Rosa sect. Caninae? Gorteria, 38: 13-21.

Henker, H. 2000. Rosa L. In: Hegi, G. Illustrierte Flora von Mitteleuropa, ed. 3, IV(2C). Berlin: Parey.

Klášterský, I. 1968. Rosa L. In: Tutin et al., eds. Flora Europaea 2: 25-32. Cambridge: Cambridge University Press.

Koopman, W.J.M., Wissemann, V., De Kock, K., Van Huylenbroeck, J., De Riek, J., Sabatino, G.J.H., Visser, D., Vosman, B., Ritz, C.M., Maes, B., Werlemark, G., Nybom, H., Debener, T., Linde, M. \& Smulders, M.J.M. 2008. AFLP markers as a tool to reconstruct complex relationships: A case study in Rosa (Rosaceae). American Journal of Botany, 95: 353-366.

Kurtto, A., Lampinen, R. \& Junikka, L. 2004. Rosa L. In: Atlas Florae Europaeae 13: 39-117. Helsinki: Suomen Biologian Seura Vanamo.

Loos, G.H. 1996. Studien an mittel-westfälischen Wildrosen, III. Zur Abgrenzung und infraspezifischen Gliederung der Arten der Sect. Caninae DC. subsect. Caninae. Dortmunder Beiträge zur Landeskunde. Naturwissenschaftlichen Mitteilungen, 30: 24.

Maskew, R. 2015. Rosa L. In: Stace, C.A., Preston, C.D. \& Pearman, D.A. Hybrid Flora of the British Isles, pp. 69-92. Bristol: BSBI Publications. 
Mercier, D. 2014. Rosa L. In: Tison, J.-M. \& de Foucault, B. Flora Gallica, pp. 9961003. Mèze: Biotope Editions.

Ritz, C.M. \& Wissemann, V. 2003. Male-correlated non-matroclinal character inheritance in reciprocal hybrids of Rosa section Caninae (DC.) Ser. (Rosaceae). Plant Systematics and Evolution, 241: 213-221.

Rouy, G. 1900. Rosa perthensis. In: Rouy, G. \& Foucaud, J. Flore de la France 6: 430. Asnières: Les Fils de Émile Deyrolle.

van der Meijden, R. 2005. Rosa L. In: Heukels'Flora van Nederland, ed. 23, pp. 382383. Groningen: Wolters-Noordhoff.

Werlemark, G., Uggla, M. \& Nybom, H. 1999. Morphological and RAPD markers show a highly skewed distribution in a pair of reciprocal crossings between hemisexual dog-rose species, Rosa sect. Caninae. Theoretical and Applied Genetics, 98: 557-563.

Werlemark, G. 2000. Evidence of apomixis in hemisexual dogroses, Rosa section Caninae. Sexual Plant Reproduction, 12: 353-359.

Werlemark, G. \& Nybom, H. 2001. Skewed distribution of morphological character scores and molecular markers in three interspecific crosses in Rosa section Caninae. Hereditas, 134: 1-13.

Copyright retained by author(s). Published by BSBI under the terms of the Creative Commons Attribution 4.0 International Public License. 